\title{
SAPONIFIKASI-NETRALISASI ASAM OLEAT MINYAK SAWIT MENJADI FOAMING AGENT RAMAH LINGKUNGAN
}

\section{SAPONIFICATION-NEUTRALIZATION OF OLEIC ACID PALM OIL BECOME A FRIENDLY ENVIROMENTAL FOAMING AGENT}

\author{
Sri Wahyuni dan Anna Dhora \\ Program Studi Teknik Pengolahan Sawit, Politeknik Kampar \\ Jln. Teuku Muhammad, KM 2, Bangkinan, Riau, Indonesia \\ Email: yuni.tip@gmail.com \\ Makalah: Diterima 2 September 2019; Diperbaiki 25 November 2019; Disetujui 10 Desember 2019
}

\begin{abstract}
Palm oil consists of a group of fatty acids which have high detergency so that it has the potential to become the basis for foaming agents. The use of palm oil as a foaming agent is an effort to diversify palm oil derivative products by utilizing local raw materials. The foaming agent is a foaming agent that can be developed as a fire poison formula for fire fighting. The purpose of this study is to obtain the right temperature and type of alkali to produce the foaming agent with the best characteristics of the results of the saponification process of neutralizing palm fatty acids with alkali $\mathrm{NaOH}$ and $\mathrm{KOH}$. The study consisted of three stages: the preparation phase, the foaming agent synthesis stage and the product characterization stage. The foaming agent synthesis was carried out according to the experimental design through the neutralization of the oleic acid feed saponification process, which was added with a 30\% alkaline solution (NaOH and $\mathrm{KOH}$ ) calculated using the saponification value of palm oil oleic acid. The research process was carried out at a temperature variation of $50^{\circ} \mathrm{C}, 70^{\circ} \mathrm{C}, 90^{\circ} \mathrm{C}$, and $110^{\circ} \mathrm{C}$ with a stirring speed of $250 \mathrm{rpm}$ for 90 minutes. Comparison of the molar ratio between oleic acid and lye/alkali solution is 1: 1 Observation was made on the quality and performance of foaming agents as products. The results of the analysis of the quality of $\mathrm{Na} / \mathrm{K}$-oleate foaming agent, showed that $\mathrm{Na}$-Oleate at $50^{\circ} \mathrm{C}$ has produced the best foaming agent with the following characteristics: acidity (pH) value 8.17, density $1.0662 \mathrm{~g} / \mathrm{cm}^{3}$, viscosity $1.07 \mathrm{cP}$, surface tension 17.76 dyne/cm, $32.10 \%$ foam stability and $50 \%$ emulsion stability.
\end{abstract}

Keywords: foaming agent, palm fatty acids, alkali

\section{ABSTRAK}

Minyak sawit terdiri dari sekumpulan asam lemak yang memiliki daya deterjensi yang tinggi sehingga berpotensi menjadi bahan dasar foaming agent. Pemanfaatan minyak sawit sebagai foaming agent merupakan salah satu upaya diversifikasi produk turunan minyak sawit dengan memanfaatkan bahan baku lokal. Foaming agent adalah bahan pembentuk busa yang dapat dikembangkan sebagai bahan formula racun api untuk pemadam kebakaran. Tujuan dari penelitian ini adalah untuk mendapatkan suhu dan jenis alkali yang tepat untuk menghasilkan foaming agent dengan karakteristik terbaik dari hasil proses saponifikasi netralisasi asam lemak sawit dengan alkali $\mathrm{NaOH}$ dan $\mathrm{KOH}$. Penelitian terdiri tiga tahap yaitu tahap persiapan, tahap sintesis foaming agent dan tahap karakterisasi produk. Sintesis foaming agent dilakukan sesuai rancangan percobaan melalui proses saponifikasi netralisasi umpan asam oleat yang ditambahkan larutan alkali $30 \%(\mathrm{NaOH}$ dan $\mathrm{KOH})$ yang dihitung menggunakan safonification value dari asam oleat minyak sawit. Proses penelitian dilakukan pada variasi suhu $50^{\circ} \mathrm{C}, 70^{\circ} \mathrm{C}, 90^{\circ} \mathrm{C}$, dan $110^{\circ} \mathrm{C}$ dengan kecepatan pengadukan $250 \mathrm{rpm}$ selama 90 menit. Perbandingan rasio molar antara asam oleat dengan lye/larutan alkali adalah 1:1 Pengamatan dilakukan terhadap kualitas dan kinerja foaming agent sebagai produk. Hasil analisis kualitas foaming agent $\mathrm{Na} / \mathrm{K}$-oleat, menunjukkan bahwa Na-oleat pada suhu $50^{\circ} \mathrm{C}$ telah menghasilkan foaming agent terbaik dengan karakteristik sebagai berikut nilai derajat keasaman $(\mathrm{pH}) 8,17$, densitas $1,0662 \mathrm{~g} / \mathrm{cm}^{3}$, viskositas $1,07 \mathrm{cP}$, tegangan permukaan 17,76 dyne/cm, stabilitas busa $32,10 \%$ dan stabilitas emulsi $50 \%$.

Kata kunci:foaming agent, asam lemak, alkali

\section{PENDAHULUAN}

Indonesia sebagai negara penghasil sawit terbesardi dunia, sampai saat ini hanya mampu mengolah produk hilir minyak sawit menjadi tiga produk turunan dalam skala industri besar yaitu minyak goreng, margarin dan biodiesel. Lebih dari
$70 \%$ hasil sawit di ekspor dalam bentuk minyak sawit kasar dan hanya sebagian kecil dalam bentuk produk turunan (GAPKI, 2017). Oleh karena itu, diperlukan upaya lebih lanjut diversifikasi produk hilir berbasis minyak sawit.

Terdapat banyak jenis ragam produk turunan dari minyak sawit diantaranya adalah 
emulsifier, moisturizer, bahan aditif, pelumas, surfaktan dan foaming agent. Foaming agent atau agen pembusa adalah bahan yang dapat membentuk busa seperti surfaktan atau blowing agent, sehingga bahan ini mampu menurunkan tegangan permukaan, tegangan antarmuka dan meningkatkan kestabilan pembentukan busa. Busa (foam) yang terbentuk berupa gelembung gas yang dibungkus oleh lapisan cairan. Busa pada foaming agent ini sama seperti sabun. Sabun adalah garam karboksilat alkali (RCOONa) dengan gugus $\mathrm{R}$ (hidrofobik) yang bersifat non polar dan kelompok COONa hidrofilik yang bersifat polar (Rais et al., 2008). Proses yang digunakan dalam sintesis foaming agent ini adalah proses safonifikasi netraliasi antara asam lemak oleat sawit dengan alkali. Melalui proses reaksi saponifikasi netralisasi dengan larutan alkali $\mathrm{NaOH}$ dan $\mathrm{KOH}$ maka akan dihasilkan sabun sebagai agen pembusa dengan jenis Na-oleat, dan K-oleat (Rivai et al., 2017). Foaming agent selain banyak diaplikasikan pada produk personal care juga mulai dikembangkan sebagai bahan formula racun api untuk pemadam kebakaran.

Sebagai negara yang memiliki hutan yang sangat luasmaka Indonesia menjadi salah satu negara yang berpotensi mengalami kebakaran hutan dan lahan setiap musim kemarau. Khususnya Provinsi Riau dengan potensi daerah sebagai sumber penghasil sawit dengan klimatologi dan topografi yang mendukung, sehingga sangat rentan terhadap terjadinya kebakaran hutan dan lahan. Bencana kebakaran hutan dan lahan yang sangat luas dan mengakibatkan bencana asap pada level yang sangat berbahaya terjadi tahun 2015 dan 2019. Pada tahun 2019 tingkat bahaya asap berdasarkan data Informasi Konsentrasi Partikulat (PM10) BMKG Pekanbaru diterangkan bahwa pencemaran udara telah mencapai pada ambang diatas $450 \mu \mathrm{g} / \mathrm{m} 3$ yang berarti berbahaya bagi kesehatan dan dapat menyebabkan kematian. Oleh karena itu, diperlukan bahan formula racun api yang efektif dan efisien sehingga dapat mengurangi penggunaan air dalam mematikan api untuk meminimalisir kerugian yang diakibatkan oleh kebakaran hutan dan lahan. Penggunaan foaming agent sebagai racun api memiliki beberapa kelebihan yaitu dapat menghambat penyebaran asap, mencegah kontak kembali dengan oksigen yang dapat mengakibatkan api kembali menyala, dan meningkatkan efisiensi penggunaan air (Rivai et al., 2017).

Foaming agent umumnya disintesis dari minyak bumi jenis polyol. Foaming agent petroleum based perlu dicarikan sumber lain karena dapat menimbulkan pencemaran terhadap lingkungan dan limbahnya sulit terdegradasi (Krol et al., 2012). Rivai et al. (2017) menjelaskan bahwa foaming agent vegetable oil based memiliki karakteristik seperti foaming agent petroleum based, namun lebih ramah lingkungan karena dapat didegradasi dan memiliki toksisitas rendah. Beberapa penelitian telah mengembangkan foaming agent dari bahan terbaharukan seperti protein, resin, dan saponin (Amran et al., 2015), namun terkendala untuk pengembangan dalam skala besar karena bahan bakutidak mencukupi dan proses produksi yang rumit serta tidak ekonomis. Penelitian sintesis foaming agent untuk firefighting agent, juga dilakukan dari asam lemak rantai panjang namun memiliki kelemahan life time busa yang lebih pendek dibandingkan syntetic firefighting agent (Mizuki et al., 2007; Mizuki et al., 2010). Penelitian Kozeta et al. (2011) menggunakan reaksi saponifikasi pada pembuatan foaming agent dari soap stock minyak biji bunga matahari dihasilkan rendemen sabun murni adalah 98,37\% (w/w). Etil ester minyak sawit direaksikan dengan logam natrium menjadi natrium asam lemak untuk firefighting agent mempunyai lifetime busa selama 345 jam (Raphael, 2013). Penelitian lainnya menggunakan K-laurat dan K-oleat yang ditambahkan MGDA (Methylglycne-N,N-Diacetic Acid) menghasilkan firefighting agent (Oguike 2013), dan memiliki expansion ratio 9,6 kali lipat dibandingkan dari firefighting foam komersial (Kawahara et al., 2016). Adapun penelitian tebaru telah dihasilkan foaming agent $\mathrm{Na} / \mathrm{K}$-laurat yang disintesis dari asam lemak laurat sawit dengan alkali (Pradesi et al., 2017). Namun, komponen asam laurat pada minyak sawit sangat kecil sehingga ketersediaannya terbatas dan sulit diperoleh.

Provinsi Riau sebagai penghasil sawit terbesar di Sumatera sangat berpotensi untuk mengembangkan produk hilir foaming agent, karena lebih mudah memperoleh bahan baku dan ketersediaannya lebih berlimpah. Terjadinya kabakaran hutan dan lahan yang luas pada tahun 2019 ini di beberapa wilayah seperti Provinsi Riau, Jambi, dan Kalimantan menyebabkan kebutuhan akan ketersediaan foaming agent akan terus meningkat setiap tahun. Kebutuhan foaming agent di Indonesia mencapai 12.870 ton/pertahun (GAPKI, 2017) dan akan terus mengalami peningkatan. Penelitian pemanfaatan minyak sawit sebagai foaming agent perlu terus dilakukan untuk mendukung upaya pengembangan diversifikasi produk hilir turunan minyak sawit yang merupakan bahan lokal, sehingga cita-cita menuju kemandirian dan peningkatan daya saing bangsa dapat tercapai. Secara khusus diharapkan bahwa foaming agent yang dihasilkan nantinya dapat dimanfaatkan langsung untuk membantu pemerintah dalam menanggulangi masalah kebakaran hutan yang rutin terjadi di Propinsi Riau terutama di Kabupaten Kampar, Rokan Hilir dan Palalawan yang memiliki titik api terbesar. Adapun tujuan dari penelitian ini adalah untuk medapatkan suhu dan jenis lye/larutan alkali yang tepat untuk menghasilkan foaming agent dengan karakteristik terbaik dari hasil proses saponifikasi netralisasi asam lemak sawit dengan alkali $\mathrm{NaOH}$ dan $\mathrm{KOH}$. 


\section{BAHAN DAN METODE}

\section{Tempat dan Waktu}

Penelitian dilaksanakan di laboratorium kimia dan laboratorium uji Program Studi Teknik Pengolahan Sawit, Politeknik Kampar. Penelitian dilaksanakan selama 5 bulan, dimulai pada bulan April-Agustus tahun 2019.

\section{Alat dan Bahan}

Peralatan yang digunakan pada penelitian ini adalah motor pengaduk, mixer, beaker glass, spatula, gelas ukur, termometer, timbangan analitik, hot plate, piknometer, homogenizer, tabung reaksi dan rak, penggaris, pipa kapiler, viskositas, $\mathrm{pH}$ meter dan alat-alat analisis lainnya.

Bahan yang digunakan terdiri dari bahan utama untuk sintesis foaming agent dan bahan untuk analisis. Bahan utama terdiri dari asam oleat dari PT Wilmar Nabati Indonesia, alkali teknis $(\mathrm{NaOH}$ dan $\mathrm{KOH})$, dan aquadest. Asam oleat digunakan sebagai bahan utama dalam pembuatan foaming agent yang bertindak sebagai asam lemak, sedangkan alkali ( $\mathrm{NaOH}$ dan $\mathrm{KOH}$ ) berfungsi sebagai bahan penetral pada reaksi saponifikasi (netralisasi) dalam pembuatan foaming agent dan aquadest digunakan sebagai bahan pelarut untuk melarutkan alkali.

\section{Tahapan Penelitian}

Persiapan Sampel

Tahap persiapan sampel meliputi dua kegiatan yaitu preparasi alat dan bahan sampel dan karakterisasi asam lemak oleat yang digunakan yaitu analisis bilangan asam (SNI 01-3555-1988), bilangan penyabunan (SNI 01-3555-1998), bilangan iod (SNI 01-3555-1998), densitas (SNI 1973 : 2016), warna (visual), titik leleh (Material Safety Data Sheet), dan titik didih (Material Safety Data Sheet).

\section{Sintesis Foaming Agent \\ Tahap selanjutnya dilakukan sintesis foaming agent yang mengacu pada penelitian} Pradesi (2018) yang dimodifikasi, sesuai rancangan percobaan melalui proses saponifikasi netralisasi umpan asam oleat yang dipanaskan sesuai variasi suhu perlakuan yang ditambahkan larutan alkali $30 \%$ (lye $\mathrm{NaOH}$ dan lye $\mathrm{KOH}$ ). Kebutuhan lye dihitung berdasarkan saponification value asam oleat, minyak sawit.Perbandingan rasio molar antara asam oleat dengan lye adalah $1: 1$ pada suhu $50^{\circ} \mathrm{C}, 70^{\circ} \mathrm{C}, 90^{\circ} \mathrm{C}$, dan $110^{\circ} \mathrm{C}$ dengan kecepatan pengadukan $250 \mathrm{rpm}$ selama 90 menit. Diagram alir proses pembuatan foaming agent disajikan pada Gambar 1.
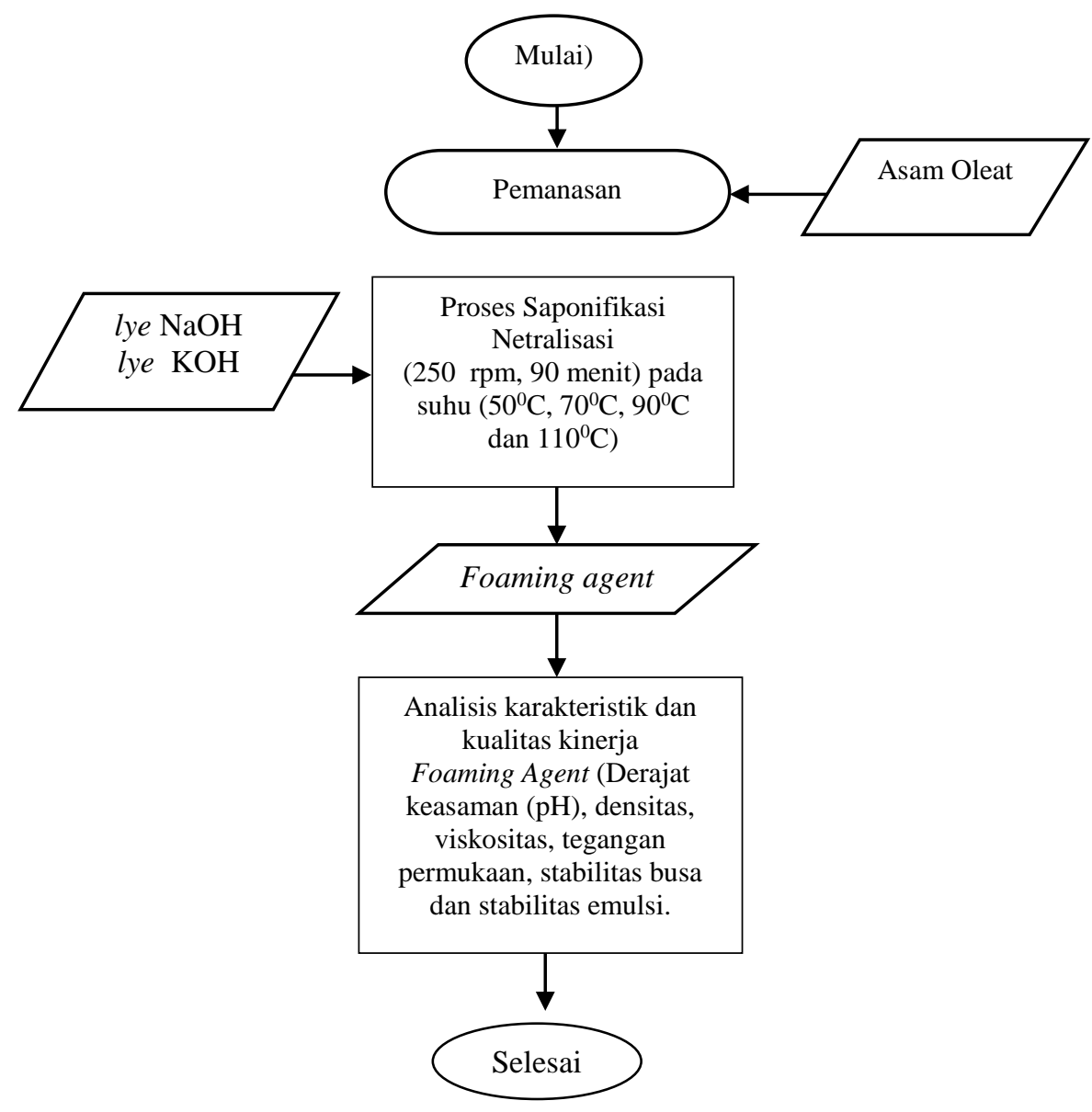

Gambar 1. Diagram alir proses pembuatan foaming agent 


\section{Rancangan Percobaan}

Rancangan penelitian menggunakan model Rancangan Acak Lengkap (RAL) dengan dua factor perlakuan yaitu jenis alkali (A) dan suhu proses (B). Jenis alkali terdiri atas 2 taraf, yaitu: $\mathrm{A} 1: \mathrm{NaOH}$ $30 \%$, A2 : $\mathrm{KOH} 30 \%$, dan suhu proses reaksi terdiri atas 4 taraf, yaitu: $\mathrm{C} 1: 50^{\circ} \mathrm{C}, \mathrm{C} 2: 70^{\circ} \mathrm{C}, \mathrm{C} 3: 90^{\circ} \mathrm{C}, \mathrm{C} 4$ : $110^{\circ} \mathrm{C}$. Data dianalisis dengan Anova dan Uji lanjut pada taraf $5 \%$. Model matematika dari rancangan percobaan penelitian ini adalah sebagai berikut:

$$
\text { Keterangan: } Y_{i j k l}=\mu+A_{i}+B_{j}+A_{i j}+\varepsilon_{i j k}
$$

$$
\begin{aligned}
& \mathrm{Y}_{\mathrm{ijk}}=\text { variabel } \mathrm{respon} / \text { hasil pengamatan } \\
& \mu=\text { Pengaruh rata-rata sebenarnya (rata- } \\
& \text { rata umum) } \\
& \mathrm{A}_{\mathrm{i}}=\text { Pengaruh factor jenis alkali (A) pada } \\
& \text { taraf ke-I }(i=\mathrm{NaOH} 30 \% \text { dan } \mathrm{KOH} \\
& 30 \% \\
& \mathrm{~B}_{\mathrm{j}} \quad=\text { Pengaruh faktor suhu roses (B) pada } \\
& \text { taraf ke-j }\left(j=50^{\circ} \mathrm{C}, 70^{\circ \mathrm{C}}, 90^{\circ} \mathrm{C}\right. \text {, dan } \\
& \left.110^{\circ} \mathrm{C}\right) \\
& \mathrm{AB}_{\mathrm{ij}}=\text { Pengaruh interaksi antara faktor } \mathrm{A} \\
& \text { taraf ke-I dan faktor B taraf ke-j } \\
& \varepsilon_{\mathrm{ijk}}=\text { Galat atau error dari factor } \mathrm{A} \text { taraf ke- }
\end{aligned}
$$

\section{Analisis Sifat Fisiko-kimia Foaming Agent}

Tahap ketiga dilakukan karakterisasi dan uji kualitas lapangan produk foaming agent yang dihasilkan yang meliputi uji nilai pH (SNI 066989.11-2004), densitas (SNI 1973: 2016), viskositas (SNI 0936: 2008), tegangan permukaan (Juliyano et al., 2005), stabilitas busa (Goon et al.,1999), dan stabilitas emulsi (Goon et al.,1999).

\section{HASIL DAN PEMBAHASAN}

\section{Karakteristik Asam Oleat}

Bahan baku yang digunakan dalam proses sintesis foaming agent ini adalah asam oleat dari minyak sawit. Asam oleat merupakan salah satu hasil fraksinasi asam lemak minyak sawit yang berwujud cair. Sebelum dilakukan proses saponifikasi netralisasi dilakukan karakterisasi terhadap asam oleat yang digunakan, sehingga diperoleh hasil uji berupasifat fisiko kimia asam oleat. Adapun sifat fisikokimia asam oleat yang dianalisis meliputi densitas, bilangan asam, bilangan penyabunan, bilangan iod, titik leleh, dan titik didih. Hasil karakterisasi sifat fisiko-kimia asam lemak oleat minyak sawit yang digunakan dapat dilihat pada Tabel 1.

Berdasarkan sifatfisiko-kimiapada Tabel 1, diketahui bahwa asam oleat memiliki nilai densitas yang lebih rendah dari minyak dan air. Karakteristik yang paling penting dan berpengaruh terhadap proses saponifikasi netralisasi dalam proses sintesis foaming agent adalah bilangan penyabunan asam oleat. Hal ini disebabkan karena bilangan penyabunan (saponification value) akan mempengaruhi perhitungan jumlah alkali untuk membuat lye atau larutan alkali yang digunakan dalam proses saponifikasi netralisasi asam oleat pada sintesis foaming agent Wahyuni, 2019).

\section{Sifat Fisiko-Kimia Foaming Agent}

Foaming agent merupakan bahan yang berfungsi untuk menghasilkan busa ketika dilarutkan dalam air pada konsentrasi rendah. Foaming agent dihasilkan dari proses saponifikasinetralisasi antara asam oleat dengan lye/larutan alkali. Pada proses ini tidak dihasilkan hasil samping berupa gliserol karena yang digunakan bukan trigliserida. Reaksi saponifikasi-netralisasi asam oleat ini menggunakan dua jenis lye/larutan alkali yaitu lye $\mathrm{NaOH}$ dan lye $\mathrm{KOH}$ (Gambar 1).

Foaming agent yang dihasilkan dari proses saponifikasi netralisasiantara asam oleat sawit dengan kedua jenis lye/larutan alkali tersebut memiliki karakteristik, wujud dan tekstur yang berbeda. Adanya perbedaan wujud dan tekstur produk foaming agent yang dihasilkan diduga karena pengaruh tipe pengadukan, hal ini dibandingkan dengan hasil penelitian (Rivai et al. 2017). Wujud dan tekstur produk juga dipengaruhi oleh sifat alkali yang digunakan pada proses saponfikasi netralisasi.

Penggunaan jenis alkali $\mathrm{NaOH}$ pada proses sintesis foaming agent menyebabkan produk langsung mengeras sehingga diperlukan mixer dengan tipe pengadukan yang lebar sehingga dapat mencapai seluruh sudut mixer. Foaming agent KOleat memiliki wujud gel-flat dengan tekstur yang lebih lembut sedangkan Na-Oleat secara umum dihasilkan foaming agent dengan wujud padat dan bertekstur menyerupai flat-butiran.

Jenis alkali $\mathrm{NaOH}$ digunakan pada pembuatan sabun keras, sedangkan jenis alkali $\mathrm{KOH}$ digunakan pada pembuatan sabun lunak sampai cair (Cavitch, 1997). Reaksi saponifikasi netralisasi asam oleat dengan lye di sajikan pada Gambar 2.

Tabel 1. Sifat fisiko-kimia asam oleat yang digunakan

\begin{tabular}{lccc}
\hline \multicolumn{1}{c}{ Parameter $\mathbf{u j i}$} & Satuan & Asam Oleat & Rivai et al. $(\mathbf{2 0 1 7})$ \\
\hline Densitas & $\mathrm{g} / \mathrm{cm}^{3}$ & $0,889-0,895\left(30^{\circ} \mathrm{C}\right)$ & $0,858\left(70^{\circ} \mathrm{C}\right)$ \\
Bilangan asam & $\mathrm{mg} \mathrm{KOH} / \mathrm{g}$ sampel & 196 & 199,2 \\
Bilangan penyabunan & $\mathrm{mg} \mathrm{KOH} / \mathrm{g}$ sampel & 196 & 200,2 \\
Bilangan iod & $\mathrm{g} / 100 \mathrm{~g}$ sampel & 120 & 87,7 \\
Warna & - & Kuning terang & - \\
Titik nyala & ${ }^{\circ} \mathrm{C}$ & \pm 360 & - \\
Titik tuang & ${ }^{\circ} \mathrm{C}$ & $\pm 13,5$ & - \\
\hline
\end{tabular}


$\|$ $\mathrm{H}-\mathrm{O}-\mathrm{C}-\mathrm{R}_{1}+\mathrm{XOH}$
$\mathrm{O}$ \|\| $\longrightarrow \mathrm{X}-\mathrm{O}-\mathrm{C}-\mathrm{R}_{1}+\mathrm{H}_{2} \mathrm{O}$

Asam lemak Alkali Sabun (foaming agent)Air

Gambar 2. Reaksi saponifikasi netralisasi asam lemak(Sudarmadji et al. 1989)

Berdasarkan Gambar 2 dapat diketahui bahwa rasio mol yang digunakan dalam proses netralisasi antara asam lemak dan lye (larutan alkali) $30 \%$ adalah 1:1. Pada proses ini dihasilkan $1 \mathrm{~mol}$ sabun sebagai foaming agent $(\mathrm{R}-\mathrm{COONa} / \mathrm{K}$ atau $\mathrm{Na} / \mathrm{K}$-Oleat). Produk foaming agent yang dihasilkan dari saponifikasi netralisasi dipengaruhi oleh konsentrasi larutan alkali, suhu reaksi, pengadukan, dan waktu reaksi.

Kualitas foaming agent yang dihasilkan dapat dilihat dari karakteristik sifat fisiko-kimia produk yang dihasilkan. Foaming agent yang baik karakteristiknya diperlukan untuk aplikasi pemadam kebakaran di lapangan yang ditentukan oleh kualitas busa yang dihasilkan. Hasil penelitian menunjukkan bahwa secara umum, karakteristik sifat fisiko-kimia foaming agent yang dihasilkan berbeda tergantung dari jenis lye / larutan alkali yang digunakan dan juga dipengaruhi oleh suhu kondisi proses yang digunakan.

\section{Derajat Keasaman (pH)}

Nilai $\mathrm{pH}$ merupakan angka yang menyatakan identitas atau derajat keasaman suatu larutan. Menurut Rondinini et al. (2001) nilai pH berkaitan dengan konsentrasi ion hidrogen sebagai bagian komponen keasaman dan konsentrasi ion hidroksil sebagai bagian komponen kebasaan. Apabila konsentrasi ion hidrogen lebih besar dibanding ion hidroksil maka larutan bersifat asam dengan $\mathrm{pH}<7$. $\mathrm{NaOH}$ dan $\mathrm{KOH}$ sebagai reaktan pada proses foamingagent bersifat basa kuat, sehingga foaming agent yang dihasilkan bersifat basa. Berdasarkan percobaaan yang dilakukan, diperoleh hasil derajat keasaman foaming agent yang berkisar antara 7,71 - 8,67. Hasil pengujian derajat keasaman $(\mathrm{pH})$ dapat dilihat pada Gambar 3.

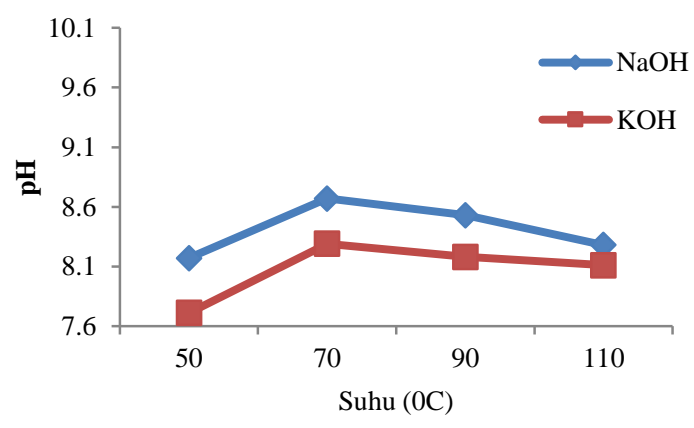

Gambar 3. Pengaruh jenis jenis alkali dan suhu terhadap $\mathrm{pH}$ foaming agent
Gambar 3 menunjukkan bahwa suhu dan jenis alkali yang digunakan berpengaruh pada nilai derajat keasaman $(\mathrm{pH})$ produk foaming agent. Peningkatan suhu sebanding dengan kenaikan derajat keasaman $(\mathrm{pH})$ hingga dicapai suhu optimal, dan selanjutnya derajat keasamanakan turun nilainya seiring meningkatnya suhu. Hasil penelitian menunjukkan bahwa suhu optimum proses saponifikasi netralisasi diperoleh pada suhu $70^{\circ} \mathrm{C}$. Hasil percobaan ini sejalan dengan penjelasan Karamah et al.(2010), bahwa apabila suhu optimum telah tercapai, maka penambahan suhuakan menurunkan efektivitas $\mathrm{pH}$. Pada percobaan ini nilai $\mathrm{pH}$ tertinggi diperoleh pada perlakuanan foaming agent $\mathrm{Na}$-Oleat suhu $70^{\circ} \mathrm{C}$ yaitu 8,67 sedangkan $\mathrm{pH}$ terendah diperoleh pada perlakuan foaming agent $\mathrm{K}$ Oleat suhu $50^{\circ} \mathrm{C}$ yaitu 7,71. Secara umum menunjukkan bahwa nilai derajat keasaman $(\mathrm{pH})$ foaming agentyang dihasilkan bersifat basa.Derajat keasaman $(\mathrm{pH})$ Foaming agent $\mathrm{RCCONa} / \mathrm{Na}-\mathrm{Oleat}$ lebih tinggi dibanding derajat keasaman RCCOK/KOleat, yang diduga disebabkan oleh perbedaan efektifitas jenis alkali dalam proses saponifikasi netralisasi asam lemak oleat.

Apabila dibandingkan dengan hasil penelitian Pradesi et al. (2017) yang menggunakan asam laurat diperoleh nilai pH 9,63 - 9,99, maka nilai $\mathrm{pH}$ foaming agent yang dihasilkan pada penelitian ini lebih rendah diduga karena pengaruh jenis asam lemak dan jumlah alkali yang digunakan berbeda. Pada penelitian sintesis foaming agent ini jumlah alkali yang digunakan lebih sedikit disebabkan karena metode perhitungan kebutuhan lye berdasarkan pada nilai SAP (saponification value) asam oleat. Nilai saponification value asam oleat menunjukkan jumlah milligram $\mathrm{NaOH} / \mathrm{KOH}$ yang diperlukan untuk menyabunkan satu gram asam oleat sehingga proses saponifikasi yang dilakukan lebih optimal. Karakteristik foaming agent yang dihasilkan sangat ditentukan oleh penggunakan jumlah alkali yang tepat. Penggunaan nilai SAP (saponification value) pada perhitungan kebutuhan lye (larutan alkali) untuk proses saponifikasi netralisasi dapat menghasilkan foaming agent dengan karakteristik dan kualitas kinerja lapang yang lebih baik (Wahyuni, 2019). Menurut Sanford etal. (2009), nilai SAP suatu asam lemak dipengaruhi oleh panjang rantai karbonnya. Rantai karbon yang panjang akan memiliki nilai SAP yang kecil. Jika panjang rantai karbon asam lemak pendek maka dalam $1 \mathrm{~g}$ lemak atau minyak memiliki banyak kandungan asam lemak, sehingga kebutuhan $\mathrm{NaOH} / \mathrm{KOH}$ untuk penyabunan tinggi. Demikian 
pula dengan massa molar, apabila massa molar asam lemak besar, maka nilai saponification value-nya kecil karena dalam $1 \mathrm{~g}$ trigliserida, asam lemak penyusunnya sedikit sehingga $\mathrm{NaOH} / \mathrm{KOH}$ yang diperlukan untuk penyabunan juga sedikit. Pada penelitian ini digunakan asam oleat yang memiliki rantai karbon panjang dan massa molarnya besar (282) sehingga nilai saponification value-nya kecil (196) dibanding asam laurat yang memiliki rantai karbon pendekdan massa molar kecil (200) sehingga saponification value-nya besar (281). Oleh karena itu, kebutuhan $\mathrm{NaOH} / \mathrm{KOH}$ untuk penyabunan asam oleat lebih kecil dibanding penyabunan asam laurat dan diduga faktor ini yang berpengaruh pada derajat keasamana produk yang dihasilkan.

Analisis ragam pada $\alpha=0,05$ menunjukkan bahwa suhu dan jenis alkali berpengaruh signifikan, sedangkan interaksi kedua faktor tidak berpengaruh signifikan terhadap derajat keasaman $(\mathrm{pH})$ foaming agent. Pada hasil uji lanjut Tukey, suhu dan jenis alkali tiap tarafnya menunjukkan hasil saling berbeda nyata.

\section{Densitas}

Densitas merupakan salah satu sifat dasar fluida yang didefinisikan massa per satuan volume. Temperatur berpengaruh pada nilai densitas cairan karena cairan akan meregang mengikuti perubahan peningkatan suhu. Densitas umumnya dikaitkan dengan viskositas dimana cairan lebih kental maka viskositasnya lebih tinggi, hal ini tentunya berkorelasi dengan kandungan total padatan pada bahan. Pengujian densitas dilakukan untuk mengetahui kerapatan antar molekul dalam sintesis foaming agent yang dihasilkan. Adapun hasil pengujian densitas foaming agent dapat dilihat pada Gambar 4.

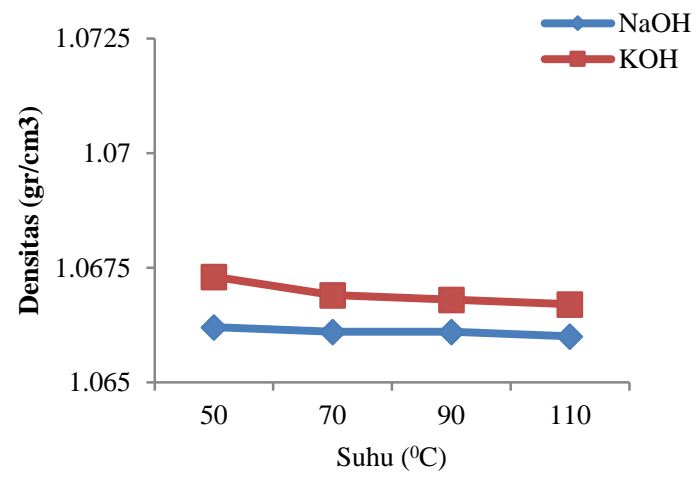

Gambar 4. Pengaruh jenis alkali dan suhu terhadap densitas foaming agent

Secara umum pada Gambar 4 menunjukkan adanya penurunaan nilai densitas. Semakin tinggi suhu yang digunakan semakin rendah nilai densitas foaming agent $(\mathrm{RCOONa} / \mathrm{K}$ atau Na-Oleat/ K-Oleat) yang dihasilkan. Nilai densitas tertinggi diperoleh dari foaming agent $\mathrm{K}-\mathrm{Oleat}$ suhu $50^{\circ} \mathrm{C}$ yaitu 1,0673 $\mathrm{g} / \mathrm{cm}^{3}$, sedangkan densitas terendah diperoleh pada pengamatan foaming agent $\mathrm{Na}$-Oleat suhu $110^{\circ} \mathrm{C}$ yaitu $1,0660 \mathrm{~g} / \mathrm{cm}^{3}$. Hal ini diduga dipengaruhi oleh konsentrasi lye karena perbedaan massa molar masing-masing alkali. Konsentrasi larutan $\mathrm{NaOH}$ yang digunakan lebih kecil dari pada konsentrasi larutan $\mathrm{KOH}$, sehingga keberadaan alkali dengan jumlah yang lebih banyak juga akan mempengaruhi nilai densitas produk foaming agent (Wahyuni 2019). Rivai et al. (2017) menjelaskan bahwa jenis alkali yang ditemukan pada produk akhir, akan mempengaruhi berat jenis produk itu sendiri. Peningkatan jumlah alkali yang ditambahkan akan meningkatkan nilai densitas. Apabila dibandingkan dengan penelitian Rivai et al. (2017) yang menggunakan bahan baku asam oleat, asam laurat dan palmitat pada suhu $70^{\circ} \mathrm{C}$ menghasilkan nilai densitas yang lebih rendah dari hasil penelitian yaitu $0,9958 \mathrm{~g} / \mathrm{cm}^{3}$.

Berdasarkan hasil analisis ragam juga menunjukkan bahwa perbedaan yang signifikan terhadap nilai densitas dipengaruhi oleh jenis alkali, sedangkan suhu dan interaksi antara kedua faktor tersebut tidak memberikan pengaruh secara signifikan pada $\alpha=0,05$. Hasil uji lanjut Tukey menunjukkan bahwa penggunaan jenis alkali $\mathrm{NaOH}$ memberikan hasil nilai densitas yang berbeda nyata dengan penggunaan alkali $\mathrm{KOH}$

\section{Viskositas}

Viskositas merupakan ukuran kekentalan fluida yang menyatakan besar kecilnya gesekan antara molekul-molekul cairan satu dengan yang lain di dalam fluida. Makin besar viskositas suatu fluida, maka makin sulit suatu fluida mengalir dan makin sulit suatu benda bergerak di dalam fluida tersebut atau sebaliknya. Sifat alir bahan tergantung pada viskositas dan densitas cairan. Cairan yang mudah mengalir dikatakan memiliki viskositas rendah (encer) dan sebaliknya bahan-bahan yang sulit mengalir memiliki viskositas yang tinggi.Adapun hasil pengujian viskositas foaming agent dapat dilihat pada Gambar 5.

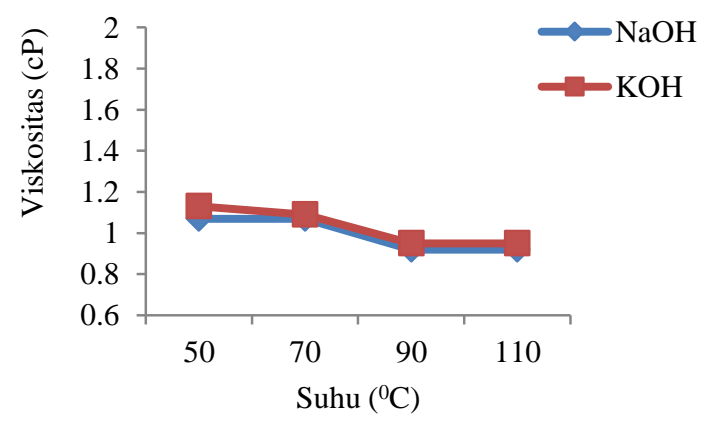

Gambar 5. Pengaruh jenis alkali dan suhu terhadap viskositas foaming agent

Berdasarkan grafik pada Gambar 5 dapat dilihat bahwa jenis alkali dan suhu memberikan pengaruh terhadap nilai viskositas. Nilai viskositas tertinggi diperoleh dari perlakuan foaming agent $\mathrm{K}$ Oleat pada suhu $50^{\circ} \mathrm{C}$ yaitu $1,13 \mathrm{cP}$, sedangkan 
viskositas terendah diperoleh dari perlakuan foaming agent Na-Oleat pada suhu $110^{\circ} \mathrm{C}$ yaitu $0,92 \mathrm{cP}$. Viskositas produk akan turun dengan meningkatnya suhu proses. Pemanasan zat cair menyebabkan molekul-molekulnya memperoleh energi sehingga molekul cairan akan bergerak yang menyebabkan gaya interaksi antar molekul melemah.

Foaming agent Na-Oleat memiliki nilai viskositas yang lebih rendah dibanding foaming agent $\mathrm{K}-\mathrm{Oleat}$. Hal ini diduga karena pengaruh jenis dan jumlah alkali yang digunakan. Penggunaan alkali $\mathrm{KOH}$ lebih banyak dibandingkan $\mathrm{NaOH}$ karena pengaruh massa molar masing-masing alkali. Massa molar $\mathrm{KOH}$ lebih tinggi maka jumlah alkali yang digunakan juga lebih banyak sehingga meningkatkan peluang terjadinya tumbukan dan interaksi antara reaktan yang berpengaruh pada nilai viskositas menjadi besar demikian juga sebaliknya. Pengaruh jumlah alkali yang ditambahkan berbanding lurus dengan peningkatan nilai viskositas produk. Menurut Holmberg et al. (2002), kenaikan viskositas disebabkan karena meningkatnya kecepatan tumbukan antar partikel, pemanasan pada zat cair menyebabkan molekul-molekulnya memperoleh energi. Molekul-molekul cairan bergerak sehingga gaya interaksi antar molekul molekul melemah, dengan demikian viskositas cairan akan turun dengan kenaikan temperatur.

Berdasarkan hasil analisis ragam didapatkan bahwa jenis alkali dan suhu berpengaruh secara signifikan terhadap nilai viskositas foaming agent, akan tetapi tidak terdapat interaksi antara kedua faktor tersebut pada $\alpha=0,05$. Hasil uji lanjut Tukey menunjukkan bahwa nilai vsikositas dari foaming agent $\mathrm{Na}$-Oleat berbeda nyata dengan $\mathrm{K}$ Oleat. Adapun suhu proses antara taraf $50^{\circ} \mathrm{C}, 70^{\circ} \mathrm{C}$ dan $90^{\circ} \mathrm{C}$ saling berbeda nyata, akan tetapi ketiga taraf tersebut tidak berbeda nyata dengan taraf $110^{\circ} \mathrm{C}$.

\section{Tegangan Permukaan}

Tegangan permukaan adalah kerja yang dilakukan untuk memperluas permukaan cairan dalam satuan luas. Tegangan permukaan terjadi karena permukaan zat caircenderung untuk menegang, sehingga permukaannya tampak seperti selaput tipis. Hal ini dipengaruhi oleh adanya gaya kohesi antara molekul air. Berdasarkan grafik pada Gambar 6 menunjukkan bahwa hasil analisis tegangan permukaan foaming agent Na-Oleat berkisar antara 17,76 - 16,71 dyne/cm, sedangkan foaming agent $\mathrm{K}-\mathrm{Oleat}$ berkisar antara 17,25 - 16,20 dyne/cm. Hasil pengujian tegangan permukaan foaming agent dapat dilihat pada Gambar 6.

Hasil penelitian menunjukkan bahwa nilai tegangan permukaan menurun dengan meningkatnya suhu, hal ini diduga karena terjadi peningkatan energi kinetik pada molekul foaming agent yang dihasilkan. Tegangan permukaan terbaik diperoleh dari nilai terendah. Nilai terendah diperoleh pada foaming agent $\mathrm{K}$-Oleat $110^{\circ} \mathrm{C}$ dengan nilai tegangan permukaan yaitu $16,20 \mathrm{dyne} / \mathrm{cm}$. Nilai tegangan permukaan dapat menunjukkan kualitas kinerja foaming agent yang dihasilkan. Makin rendah nilai tegangan permukaan maka makin bagus kualitas kinerja foaming agent. Pada umumnya nilai tegangan permukaan zat cair berkurang dengan adanya kenaikan suhu karena meningkatnya energi kinetik molekul (Juliyanto et al., 2011).

Hasil analisis ragam menunjukkan bahwa suhu, jenis alkali dan interaksi kedua faktor tersebut tidak memberikan pengaruh yang signifikan terhadap nilai tegangan permukaan dari foaming agent $(\alpha=0,05)$.

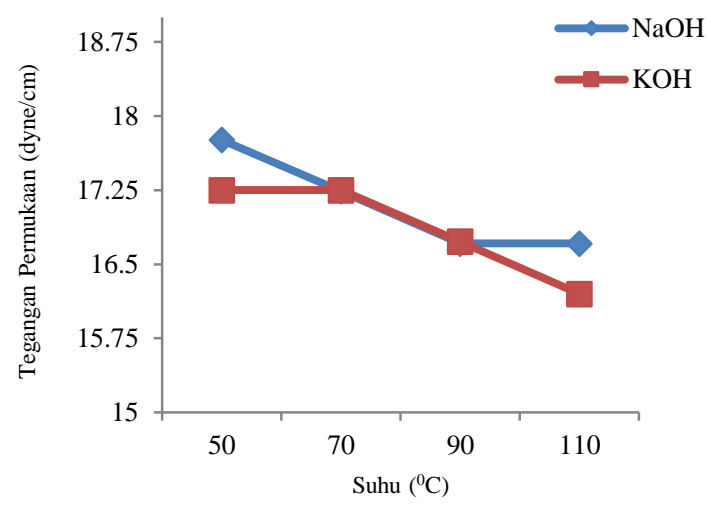

Gambar 6. Pengaruh jenis alkali dan suhu terhadap tegangan permukaan foaming agent

\section{Uji Kualitas KinerjaFoaming Agent}

Stabilitas Busa

Stabilitas busa adalah kemampuan busa untuk mempertahankan parameter utamanya seperti ukuran gelembung, kandungan cairan, dan total volume busa dalam keadaan konstan selama waktu tertentu. Analisis stabilitas busa dilakukan dengan tujuan mengetahui kemampuan busa untuk bertahan atau tidak hilang selama jangka waktu 3 hari. Hasil pengujian stabilitas busa foaming agent diperoleh dari selisih tinggi busa setelah dihomogenkanpada menit ke-0 dengan tinggi busa pada hari ke-3. Tinggi busa pada menit ke-0 dijadikan baseline untuk menganalisis stabilitas busa (Goon et al.,1999; Rivai et al., 2017; Pradesi, 2018). Hasil pengujian stabilitas busa foaming agent disajikan pada Gambar 7.

Pada Gambar 7 diperoleh informasi bahwa secara umum seluruh perlakuan mengalami penurunan tinggi busa pada pengamatan hari ke-3. Nilai stabilitas busa tertinggi diperoleh dari foaming agent Na-Oleat dan foaming agent K-Oleat pada perlakuan suhu $50^{\circ} \mathrm{C}$ engan penurunan tinggi busa masing-masing secara berurutan yaitu dari $2,8 \mathrm{~cm}$ menjadi $0,9 \mathrm{~cm}$ dengan nilai kestabilan busa dalam persen adalah sebesar 32,1\% (Na-Oleat) dan dari 4,1 $\mathrm{cm}$ menjadi $1,2 \mathrm{~cm}$ dengan nilai kestabilan busa dalam persen adalah sebesar 30\% (K-Oleat). 

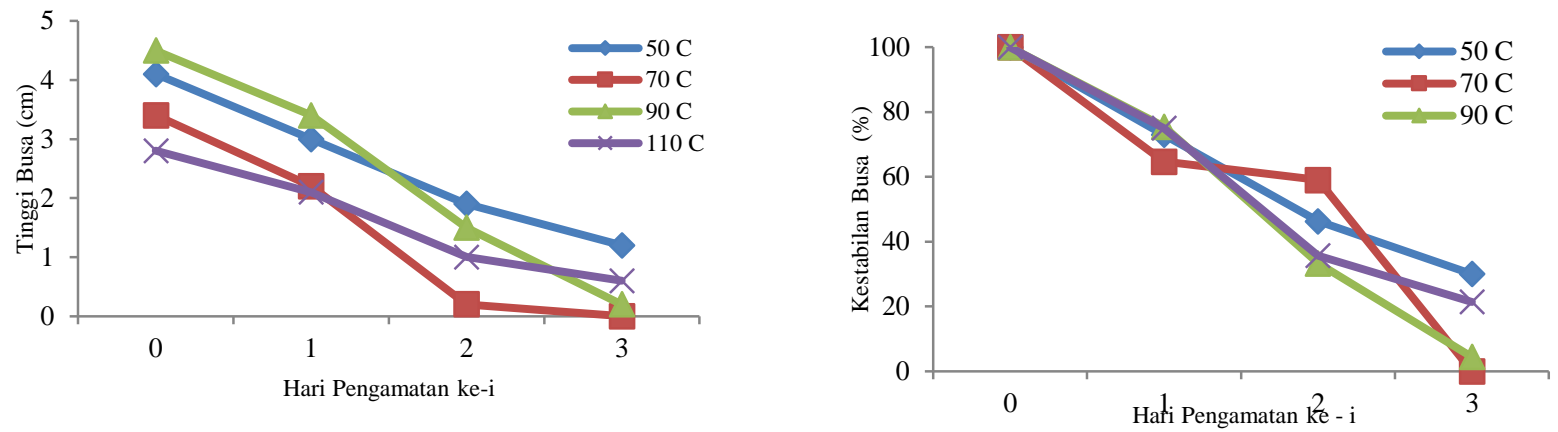

(a) Foaming AgentK-Oleat
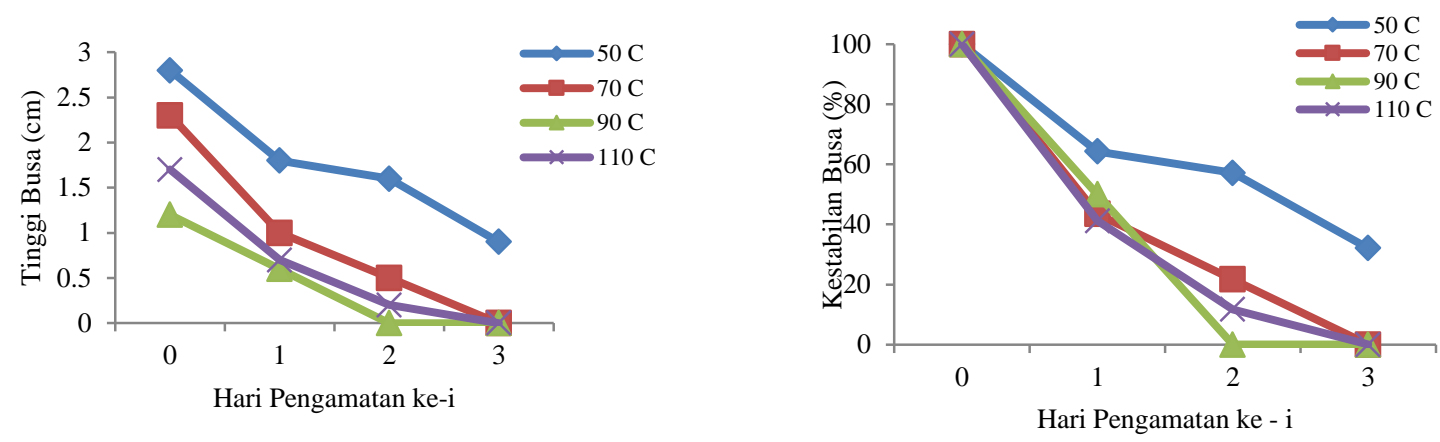

(b) Foaming Agent Na-Oleat

Gambar 7. Pengaruh jenis alkali dan suhu terhadap sabilitas busa foaming agent : (a) K-Oleat (b) Na-Oleat

Sementara untuk stabilitas busa terendah berdasarkan data dengan nilai $0 \%$ yang berarti busa tidak memiliki kestabilan yang ditunjukkan dengan penurunan tinggi busa yang besar pada setiap waktu pengamatan hingga busa habis pada pengamatan hari ke-3 yang diterlihat pada perlakuan foaming agent $\mathrm{K}-\mathrm{Oleat}$ suhu $70^{\circ} \mathrm{C}$, foaming agent $\mathrm{Na}-\mathrm{Oleat}$ suhu $70^{\circ} \mathrm{C}$, foaming agent Na-Oleat suhu $90^{\circ} \mathrm{C}$ dan foaming agent Na-Oleat suhu $110^{\circ} \mathrm{C}$. Penurunan tinggi busa ini menunjukkan bahwa kualitas busa tidak stabil yang disebabkan oleh pecahnya busabusa yang dihasilkan. Pecahnya busa disebabkan terjadinya penipisan pada lapisan film dan bergabungnya busa-busa menjadi busa yang lebih besar (Tadros, 2005).

Penipisan lapisan film tersebut karena busa memiliki kecenderungan untuk naik ke permukaan namun pada saat yang sama sekaligus ditarik ke bawah yang disebabkan gaya gravitasi aliran cairan. Karena ditarik dari dua arah maka film busa menjadi semakin tipis dan kemudian menjadi lebih mudah pecah. Ukuran busa yang bervariasi menyebabkan adanya gradien tekanan gas sehingga terjadi difusi gas, sehingga busa-busa kecil akan bergabung menjadi busa-busa yang lebih besar. Ukuran busa yang besar menunjukkan bahwa tegangan permukaan cairan dengan udara juga besar sehingga busa lebih mudah pecah (Schramm, 2005).

Hasil analisis ragam menunjukkan bahwa suhu dan jenis alkali berpengaruh signifikan pada kualitas kinerja foaming agent yang dihasilkan. Peningkatan suhu proses menyebabkan kestabilan busa menurun. Sementara berdasarkan jenis alkali, foaming agent K-Oleat lebih banyak menghasilkan busa dari pada foaming agent $\mathrm{K}-\mathrm{Na}$, hal ini diduga karena adanya pengaruh jumlah alkali yang digunakan untuk proses saponifikasi netralisasi.

\section{Stabilitas Emulsi}

Emulsi merupakan sistem dispersi yang terdiri atas dua cairan yang imisibel (tidak dapat bercampur), yaitu pada kondisi droplet suatu cairan (fase terdispersi) terdispersi pada cairan media yang lain (fase kontinyu). Untuk mendispersikan dua cairan yang imisibel diperlukan komponen ketiga, yaitu emulsifier. Nilai stabilitas emulsi didapatkan dari selisih tinggi emulsi pada menit ke- 0 setelah dihomogenkandengan tinggi emulsi pada hari ke-3 yang dinyatakan dalam satuan $\mathrm{cm}$ lalu dipersentasekan. Hasil pengujian nilai stabilitas emulsi memberikan kisaran 0-100\%. Adapun hasil pengujian stabilitas emulsi foaming agent dapat dilihat pada Gambar 8 .

Kestabilan emulsi merupakan kekuatan sistem emulsi yang berfungsi untuk mempertahankan kestabilannya dalam berbagai kondisi. Emulsi yang baik tidak membentuk lapisanlapisan, tidak terjadi perubahan warna dan memiliki konsistensi tetap (Suryani et al., 2002). 

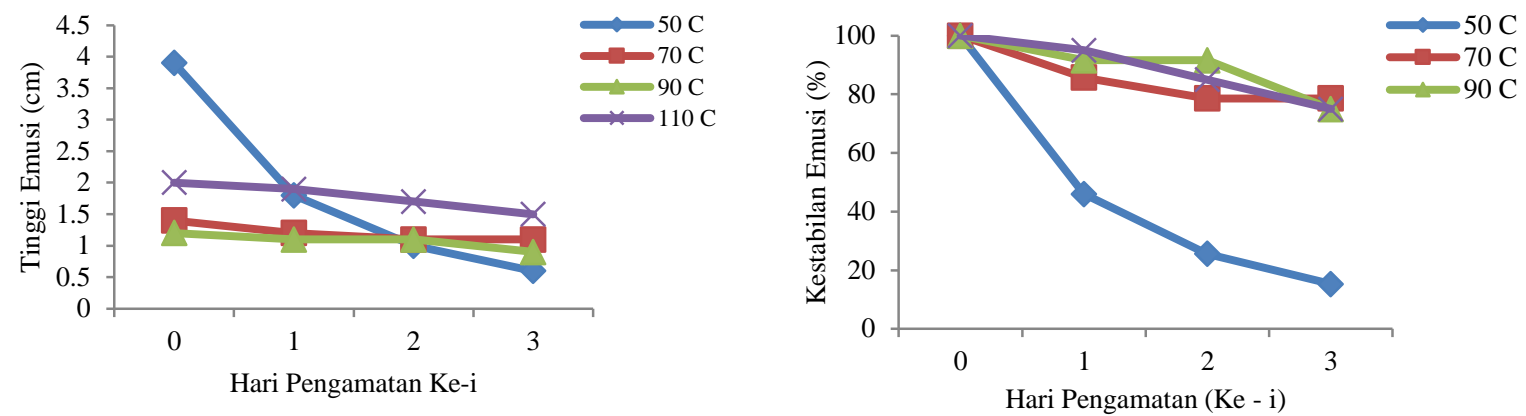

(a) Foaming AgentK-Oleat
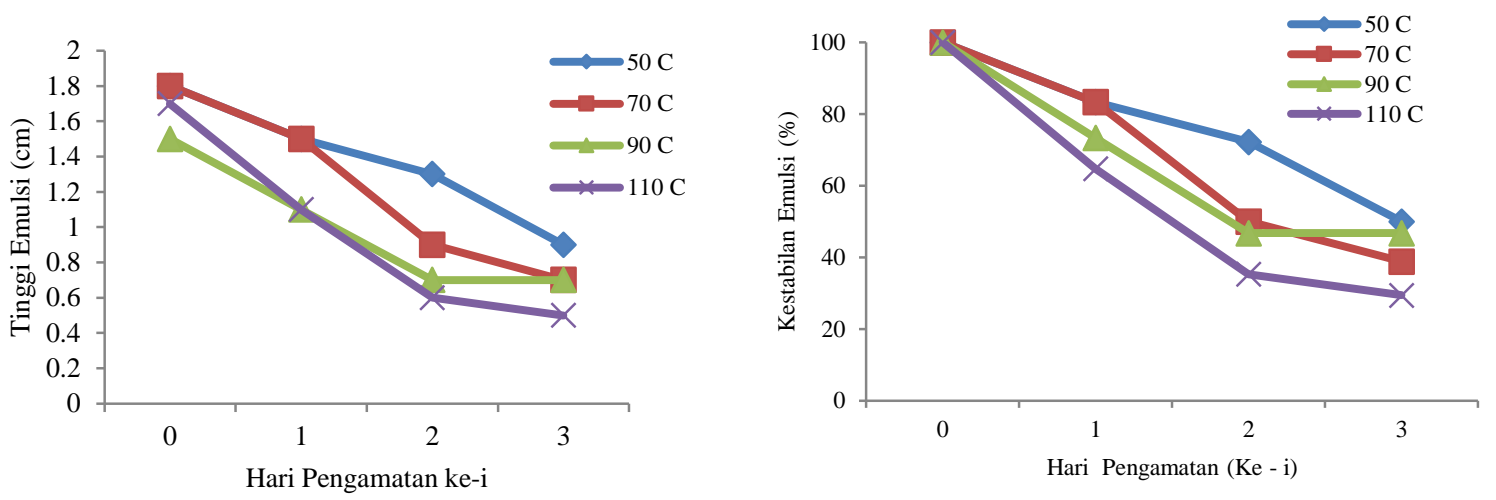

(b) Foaming Agent Na-Oleat

Gambar 8. Pengaruh jenis alkali dan suhu terhadap sabilitas emulsi foaming agent : (a) K-Oleat (b) Na-Oleat

Hasil analisis menunjukkan bahwa, nilai kestabilan emulsi foaming agent tertinggi diperoleh dari perlakuan foaming agent K-oleat pada suhu $70^{\circ} \mathrm{C}(78,6 \%)$. Sementara itu, kestabilan emulsi terendah diperoleh pada perlakuan foaming agent $\mathrm{K}$ Oleat pada suhu $110^{\circ} \mathrm{C}(15,3 \%)$. Stabilitas emulsi berhubungan dengan tegangan permukaan dan tegangan antarmuka. Apabilanilai tegangan permukaan dan tegangan antarmuka kecil maka stabilitas emulsi akan meningkat (Hasenhuetti, 2000).

\section{KESIMPULAN DAN SARAN}

\section{Kesimpulan}

Berdasarkan hasil penelitian maka dapat disimpulkan bahwa kualitas foaming agent terbaik dihasilkan dari foaming agent $\mathrm{K}$-oleat pada suhu $70^{\circ} \mathrm{C}$ dengan karakteristik sebagai berikutnilai $\mathrm{pH}$ 8,30, densitas $1,0669 \mathrm{gr} / \mathrm{cm}^{3}$, viskositas 1,09 cP, tegangan permukaan $17,25 \mathrm{dyne} / \mathrm{cm}$. Berdasarkan hasil uji stabilitas busa dan stabilitas emulsi, foaming agent $\mathrm{K}$-oleat pada suhu $50^{\circ} \mathrm{C}$ memiliki kinerja terbaik dimana busa mampu bertahan selama 3 hari pada suhu ruang.

\section{Saran}

Berdasarkan hasil penelitian perlu dilakukan penelitian lebih lanjut dengan menggunakan mixer dengan tipe pengadukan yang lebih lebar.

\section{UCAPAN TERIMA KASIH}

Terima kasih disampaikan kepada DRPM Ristek Dikti atas financial support dalam penyelesaian penelitian ini.

\section{DAFTAR PUSTAKA}

Amran YHM, Farzadnia N, Ali AAA. 2015. Properties and applications of foamed concrete; a review. Constr Build Mater. 101(1):990-1005.

Cavitch SM. 1997. The Soapmaker's Companion ; $A$ Comprehensive Guide With Recipes, Techniques \& Know-How. United States: Versa Press.

Clariant. 2009. The Foam, defoaming mechanism and products.[diunduh 2017 Januari 10].Tersedia pada: http:fun .clariant.com

Exerowa D dan Kruglyakov PM. 1998. Foam and Foam Films: Theory, Experiment, Application. Netherlands (NL): Elsevier Science.

Goon P, Bhirud RG, dan Kumar VV. 1999. Detergency and foam studies on linear alkylbenzene sulfonate and secondary alkyl sulfonate. JSurfactant Deterg. 2(4):489493.doi:10.1007/s11743-999-0097-0. 
Hassenhuetti GH. 2000. Design and Application of Fat-Based Surfactants. Di dalam: O'Brien $\mathrm{RD}$, Farr WE, Wan PJ, editor. Introduction to Fat and OilTechnology. 2nd Ed. Lllionus (US): AOAC Pr.

Holmberg K, Jonssson B, Kronberg B, Lindman B. 2002. Surfactants and Polymers in Aqueous Solution. London (UK): John Wiley \& Sons Ltd.

Juliyanto E, Rofingah J, Sejati AF, Hakim FN. 2005. Menentukan Tegangan Permukaan Zat Cair. Wonosobo (ID): Universitas Sains Al-Quran.

Karamah E dan Septiyanto A. 2010. Pengaruh Suhu dan Tingkat Keasaman (pH) Pada Tahap Perlakuan Koagulasi (Koagulan Alumunium Sulfat) dalam Proses Pengolahan Air Menggunakan Membran Mikrofiltrasi Polipropilen Hollow Fibre. Jakarta (ID): UI.

Kawahara T, Hatae S, Kanyama T, Ishizaki Y, Uezu K. 2016. Development of ecofriendly soapbased firefighting foam for forest fire. Environ Control Biol. 54(1):75-78.

Ketaren S. 2012. Pengantar Teknologi Minyak Lemak Pangan. Jakarta (ID): UI Pr.

Kozeta V, Mevlude D, dan Marku J. 2011. Production of the anionic surfactant from soapstock of the sunflower oil. Journal Natura Montenegrina. 9(3):773-783.

Król B, Prochaska K, dan Chrzanowski Ł. 2012. Biodegradability of firefighting foams. Journal Fire Technology. 48 (2): 173-181.

Mizuki H, Kazuya U, Tomonori K, Takashi K, Masataka K, Shuichi H, Yoshihiko O, Shinji I, Shota M, Yoshio N. 2007. Novel environmental friendly soap-based firefighting agent. Journal Environ Eng Manage. 17(6):403-408.

Mizuki H, Toyomura M. Uesu K, Yasui H. 2010. Microbial degradation of soap based fire fighting agent in activated sludge. $J$ Environ Eng Manage. 20(2):109-113.

[MSDS] Material Safety Data Sheet. 2018. Product Safety Summary. INVOICE NO: 2018JT5090. Bratachem Chemical.

Oguike RS. 2013. Study of fire fighting foam agent from palm oil for extinguishing of petrol fires. Science Postprint. 1(1): e00007.

Pradesi J, Hambali E, dan Warsiki E. 2017. Sintesis foaming agent asam laurat sawit dan karakteristik sifat fisikokimia. Jurnal Teknologi Industri Pertanian. 27(3):291-297.
Pradesi J. 2018. Sintesis dan karakterisasi sifat fisiko kimia foaming agent dari asam lemak sawit. Bogor. (ID): IPB.

Rafiq A, Sodik J, dan Sumarno. 2015. Penggunaan Blowing Agent Karbondioksida pada Pembuatan Polyurethane Faom Berbasis Castor Oil. Surabaya. (ID): ITS.

Rais F, Baati R, Damak N, Kamaun A. 2008. The use of a eutetic mixture of olive pomace oil fatty amides to easilly prepared sulfated amides applied as lime soap dispersant. Dispersant. 85:869-877. doi:10.1007/s11746008-1266-2.

Rivai M, Hambali E, Suryani A, Fitria R, Firmansyah S, Pradesi J. 2017. Synthesis of palm oil fatty acid as foaming agent for firefighting agent application. IOPConf Ser: Earth Environ Sci. 65.doi:10.1088/17551315/ 65/1/012047.

Rondinini S, Buck RP, dan Covington AK. 2001. The measurement of $\mathrm{pH}$-definition, standards and procedures. Journal Pure Applied Chemistry. 74 (11):2169-2200.

Sanford SD, White JM, Shah PS, Wee C, Valverde MA,Meier GR. 2009. Feedstock and Biodiesel Characteristics Report. Iowa (US): Renewable Energy Group Inc.

Schramm LL. 2005. Emulsion, Foam, and Suspensions. New Jersey (US): WileyVCHVerlag GmbH\&Co. KGaA, Weinheim. Page: 47-49.

Shinde UP, Chougule SS, Dighavkar SG, Jagadale BS, Halwar DK.2015. Surface tension as a function oftemperature and concentration of liquids. International Journal Chemical and Physical Sciences. 4(3):1-7.

Spitz L.1996. Soaps and Detergents: A Theoretical and Practical Review. Lllinois (US): AOAC Pr.

Sudarmadji S, Haryono B, dan Suhardi. 1989. Analisa Bahan Makanan dan Pertanian. Yogjakarta (ID): UGM.

Suryani A, Sailah I, dan Hambali E. 2002. Teknologi Emulsi. Bogor (ID): IPB Pr.

Tadros TF. 2005. Applied Surfactants-Principles and Applications, 259-263. New Jersey (US): Wiley VCH Verlag GmbH\&Co.Kga. 